Research Article

\title{
Kinetic and Isotherm Studies of Nitrate Adsorption in Salt Water Using Modified Zeolite
}

\author{
K. Kuntari*) \\ Chemical Analysis Study Program, Department of Chemistry, Islamic University of Indonesia, \\ Yogyakarta 55584, Indonesia.
}

Received: $8^{\text {th }}$ February 2021; Revised: 31 $1^{\text {st }}$ March 2021; Accepted: $1^{\text {st }}$ April 2021

Available online: $7^{\text {th }}$ April 2021; Published regularly: June 2021

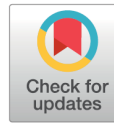

\section{Abstract}

Nitrate is the main form of nitrogen species in natural waters. Excessive nitrate concentration in water is highly undesirable, so that removal of the excessive nitrates in waters is very important. However, the challenge is purposed to remove the excessive nitrates in sea waters by considering anions-rich sea water. Adsorption is a favorable method for the nitrate removal process. Therefore, this research was aimed to study the kinetics and isotherm of nitrates adsorption in salt water. The adsorbent preparation was done by modifying natural zeolite with iron oxide. The adsorbent characterization was carried out by FT-IR spectroscopy and Gas Sorption Analysis methods. The results showed that the modified zeolite have $\mathrm{Fe}-\mathrm{O}$ group vibrations as indicated by a peak at a wave number of $1404.18 \mathrm{~cm}^{-1}$ and an increased specific surface area. The modified zeolite is capable of adsorbing nitrate ions. The adsorption isotherms studies indicated that the modified zeolite is appropriate to the Dubinin-Radushkevich model. The average adsorption energy value (ED), obtained based on the Dubinin-Radushkevich isotherm $<2$ $\mathrm{kJ} / \mathrm{mole}$, showed that the nitrate adsorption on zeolite surface occurred physically. The most suitable adsorption kinetics model is the pseudo second order with the rate constant of $1.80 \times 10^{-2} \mathrm{~g} / \mathrm{mg} . \mathrm{min}$.

Copyright (C) 2021 by Authors, Published by BCREC Group. This is an open access article under the CC BY-SA License (https://creativecommons.org/licenses/by-sa/4.0).

Keywords: Nitrate Adsorption; Zeolite Modified; Salt Water; Pseudo Second Order; Dubinin-Radushkevich

How to Cite: K. Kuntari (2021). Kinetic and Isotherm Studies of Nitrate Adsorption in Salt Water Using Modified Zeolite. Bulletin of Chemical Reaction Engineering \& Catalysis, 16(2), 286-292 (doi:10.9767/bcrec.16.2.10312.286292)

Permalink/DOI: https://doi.org/10.9767/bcrec.16.2.10312.286-292

\section{Introduction}

Nitrate $\left(\mathrm{NO}_{3}{ }^{-}\right)$is salt of nitric acid and main form of nitrogen species in natural waters. Agricultural, industrial and household wastewaters are the major sources of nitrates in the surface and ground waters [1]. Excessive nitrate leads to rapid increase in the growth of plants and algae in waters. The increasing growth in these plants and algae in the water triggers, a competition for oxygen in the water body leading to tremendous deaths of these organisms which

* Corresponding Author.

Email: kuntari.d3ak@uii.ac.id (K. Kuntari);

Telp: +62-274- 895920 Fax: +62-274-896439 eventually results in a buildup in decaying matter. This buildup and may even lead to the filling up of ponds and lakes, thus destroying or creating an imbalance in the entire ecosystem, if not dealt with in time. It is also known to trigger the loss of diversity in the sea floor community (including seaweeds, sea grasses, and corals), and amongst planktonic organisms. Since planktonic algae are the basis of marine life, their absence affects the ecological food chain and food webs tremendously.

Excessive nitrate is among the most problematic surface water and groundwater pollutants. Removal of excessive nitrates in waters is very important. It becomes a challenge to it re- 
move excessive nitrates in sea waters, considering that sea water is rich in other anions such as sulfate, bicarbonate, bromide, borate and bromide. Various methods have been developed for nitrate removal up to date [2]. The most common methods are ion exchange [3,4], reverse osmosis [5,6], electrodialysis $[7,8]$, denitrification using bacteria $[9,10]$, and adsorption [11-14]. Even though these methods have their own advantages in removing nitrate, they have some major drawbacks such as high waste disposal, formation of disinfection by products, expensive cost and operation complexity. Adsorption, on the other hand, is a more favorable method for the nitrate removal process due to its simple of design, ease of operation, and less to no waste disposal.

Natural zeolite is an abundant mineral in Indonesia, with a hollow structure and large surface area. The abundance and availability of natural zeolite makes it a relatively low cost adsorbent, but because there is no positive charge on its surface, it is difficult for the anionic pollutants to adsorb. Iron modified zeolite is effectively used to remove anionic contaminant like cyanide from aqueous solutions [15], phosphate from river sediments [16], phosphate in rainwater runoff [17], arsenate aqueous medium [18], and sulfide from river sediments [16]. There have been limited studies concerned on nitrate adsorption in saltwater. Therefore, this research intends to study nitrate adsorption by iron modified zeolite. The objectives of this research are to study kinetics and isotherms of nitrate adsorption in salt water using natural zeolites coated with iron oxide.

\section{Materials and Methods}

\subsection{Materials}

This research used some research materials including distilled water and quality chemicals made of Merck including ammonium chloride, sodium chloride, magnesium chloride hexahydrate, potassium chloride, calcium chloride dehydrate, potassium nitrate, ferric chloride hexahydrate, chloroform, sodium hydroxide, chloric acid $37 \%$, sodium salicylate, sulfuric acid 98\% and natural zeolite (PT Brataco). The main mineral component of PT Brataco's natural zeolite is $66.78 \%$ quartz [19].

\subsection{Adsorbent Preparation}

In this study, natural zeolites of 250-500 $\mu \mathrm{m}$ were used. The adsorbent used was obtained by sieving natural zeolite using a 250 and $500 \mu \mathrm{m}$ sieve. The $30 \mathrm{~g}$ of natural zeolite was then soaked with $25 \mathrm{~mL}$ of $1 \mathrm{M} \mathrm{NH}_{4} \mathrm{Cl}$ salt solution for $24 \mathrm{~h}$. Zeolites were washed using distilled water, then dried at $120^{\circ} \mathrm{C}$ for $5 \mathrm{~h}$. At this stage natural zeolite activation was obtained. Activated natural zeolite as much as 30 $\mathrm{g}$ was interacted with a solution containing 30 $\mathrm{mL} \mathrm{Fe}{ }^{3+} 0.5 \mathrm{M}$. The mixture was shaken for 15 min, then hydrolyzed by adding $1 \mathrm{M} \mathrm{NaOH}$ drops so that the $\mathrm{pH}$ reached 9. Next, the mixture is stirred for $15 \mathrm{~min}$. The resulting precipitate was heated at $50{ }^{\circ} \mathrm{C}$ for $2 \mathrm{~h}$. The result was then washed with distilled water until the $\mathrm{pH}$ of the solution was around 7. The suspension was decanted, then roasted at $70{ }^{\circ} \mathrm{C}$ for 5 $\mathrm{h}$ [19]. The adsorbent obtained in this stage was modified zeolite (MZ).

\subsection{Adsorbent Characterization}

The adsorbent used was characterized using the Shimadzu FT-IR-8201 PC infrared spectrophotometer with the solid method. The adsorbent to be analyzed was homogeneous with $\mathrm{KBr}$ powder, then pressed 2000 psi to become transparent thin pellets. The pellet was placed in the cell and spectra analysis was carried out at $300-4000 \mathrm{~cm}^{-1}$ wave number. The specific surface area and pore volume of adsorbents were measured by BET method on a Nova Win2 version 2.2 apparatus. Before measurement, the sample was heated and the degassing process is carried out at a temperature of $300{ }^{\circ} \mathrm{C}$ for $3 \mathrm{~h}$ under vacuum. Furthermore the sample was cooled with liquid nitrogen to form a single layer of nitrogen molecules on the surface of the sample. The volume of the gas or the mass of the gas adsorbed at liquid nitrogen temperature $(77.3 \mathrm{~K})$ was determined, by measuring changes in pressure and the volume or mass of gas adsorbed by the sample so the specific surface area, total pore volume, pore size distribution and adsorption isotherm of the sample analyzed could determined.

\subsection{Solution Preparation}

Salt water was made by dissolving $6.67 \mathrm{~g}$ $\mathrm{NaCl}, 0.18 \mathrm{~g} \mathrm{KCl}, 2.82 \mathrm{~g} \mathrm{MgCl}_{2} .6 \mathrm{H}_{2} \mathrm{O}$, and 0.45 g $\mathrm{CaCl}_{2} .2 \mathrm{H}_{2} \mathrm{O}$ in distilled water. The final volume of the solution was made to $250 \mathrm{~mL}$ to obtain salt water with concentration of $\mathrm{Na}^{+}$, $\mathrm{Mg}^{2+}, \mathrm{K}^{+}$, and $\mathrm{Ca}^{2+}$ of $10.50,1.35,0.38$, and $0.40 \mathrm{~g} / \mathrm{L}$, respectively.

\subsection{Isotherm Studies}

Adsorption isotherm of MZ were identified by batch experiments. Three different initial 
nitrate concentrations, i.e. $2,4,6,8$ and 10 $\mathrm{mg} / \mathrm{L} \mathrm{NO}_{3}-\mathrm{N}$, were reacted with $150 \mathrm{mg}$ of adsorbent during $24 \mathrm{~h}$. The mixture was then filtered using Whatman-41 paper. The concentration of nitrate was determined using salysilate method [20]. This study used the isotherm model of the Langmuir, Freundlich, and Dubinin Radushkevich isotherms. Langmuir's equation [21] was represented in the Equation (1).

$$
\frac{C_{e}}{q_{e}}=\frac{1}{q_{\max } K_{L}}+\frac{C_{e}}{q_{\max }}
$$

$C_{e}$ is the concentration of adsorbate in equilibrium $(\mathrm{mg} / \mathrm{L}), \quad q_{e}$ is the amount of adsorbate adsorbed at equilibrium by each gram of adsorbent $(\mathrm{mg} / \mathrm{g}), K_{\mathrm{L}}$ is the Langmuir constant $(\mathrm{L} / \mathrm{mg})$ and $q_{\max }$ is the maximum capacity of the adsorbent monolayer $(\mathrm{mg} / \mathrm{g})$. $q_{\max }$ and $K_{\mathrm{L}}$ values were calculated from slope and intercept of $C_{e} / q_{e}$ graphs versus $C_{e}$.

Freundlich adsorption isotherms [22] are presented in Equation (2), where $q_{e}$ is the amount of adsorbate adsorbed at equilibrium by each gram of adsorbent $(\mathrm{mg} / \mathrm{g}), K_{\mathrm{F}}$ is the Freundlich constant $(\mathrm{L} / \mathrm{g}), C_{e}$ is the concentration of adsorbate in equilibrium $(\mathrm{mg} / \mathrm{L})$ and $n$ is the adsorption intensity.

$$
q_{e}=K_{F} \cdot C_{e}^{1 / n}
$$

Equation (2) if transformed into a linear equation into Equation (3) can be written as follows:

$$
\log q_{e}=\log K_{F}+\left(\frac{1}{n}\right) \log C_{e}
$$

The linear form of the Dubinin-Radushkevich isotherm equation [23] is written in Equation (4):

$$
\ln q_{e}=\ln Q_{D}-B_{D} \varepsilon^{2}
$$

$Q_{\mathrm{D}}$ is the maximum capacity $(\mathrm{mmol} / \mathrm{g}), B_{\mathrm{D}}$ is the Dubinin-Radushkevich constant $\left(\mathrm{mol}^{2} . / \mathrm{kJ}{ }^{2}\right)$

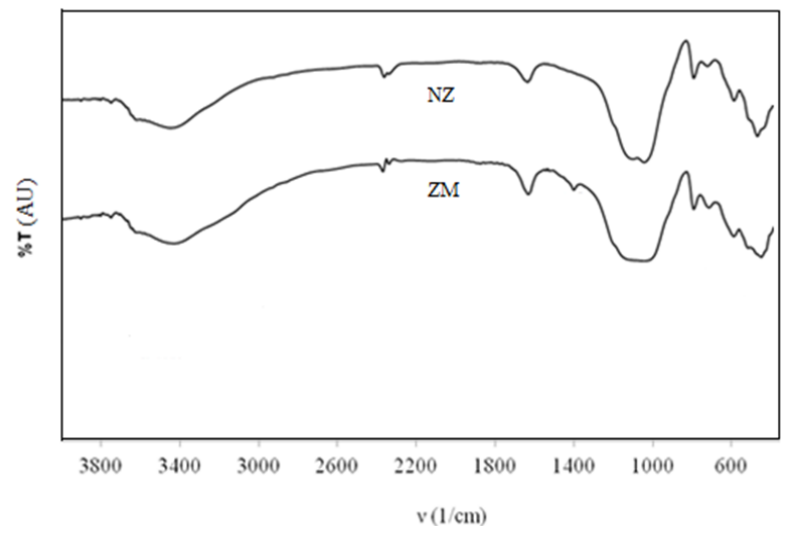

Figure 1. FT-IR spectra of natural zeolite (NZ) and modified zeolite (MZ). and $\varepsilon$ is the Polanyi potential obtained from Equation (5):

$$
\varepsilon=R T \ln \left(1+\frac{1}{C_{e}}\right)
$$

Average adsorption energy $\left(E_{\mathrm{D}}\right)(\mathrm{kJ} / \mathrm{mol})$ can be calculated from Equation (6):

$$
E_{D}=\frac{1}{\sqrt{2 B_{D}}}
$$

\subsection{Kinetic Studies}

The kinetics study was carried out using a solution containing $10 \mathrm{mg} / \mathrm{L} \mathrm{NO}_{3}-\mathrm{N}$ as much as $15 \mathrm{~mL}$ interacted with $\mathrm{MZ}$ as much as $150 \mathrm{mg}$. The time variations used were $60,90,120,150$, 180 , and $210 \mathrm{~min}$. In this study the kinetics of adsorption were studied using two models, namely pseudo-first-order Lagergren and pseudo-second-order. The pseudo-first-order kinetic model of Lagergren [24] was given by Equation (7).

$$
\ln \left(q_{e}-q_{t}\right)=\ln q_{e}-k t
$$

$q_{e}$ is the adsorption capacity at equilibrium $(\mathrm{mg} / \mathrm{g}), q_{t}$ is the adsorption capacity at a certain time $(\mathrm{mg} / \mathrm{g})$, and $k$ is the constant rate of the pseudo order reaction of one $(1 / \mathrm{min}))$. The pseudo-second-order kinetic model [25] is, presented in Equation (8).

$$
\frac{t}{q_{t}}=\frac{1}{k q_{e}^{2}}+\frac{t}{q_{e}}
$$

$q_{e}$ is the adsorption capacity at equilibrium $(\mathrm{mg} / \mathrm{g}), q_{t}$ is the adsorption capacity at a given time $(\mathrm{mg} / \mathrm{g})$, and $k$ is the rate constant of the pseudo- second-order (g/mg.min).

\section{Results and Discussion}

\subsection{Adsorbent Characterization}

Figure 1 presents the FTIR spectrum of NZ compared to MZ. The coating of natural zeolites with iron oxide involves interactions be-

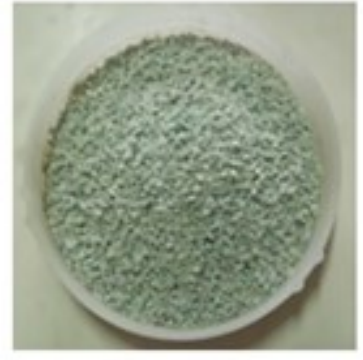

(a)

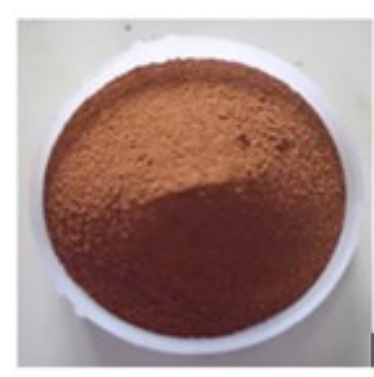

(b)
Figure 2. Change in the colour (a) NZ, (b) MZ. 
tween the groups found in iron oxide and $\mathrm{SiO}_{4}$. The vibration of the $\mathrm{Fe}-\mathrm{O}$ group is shown by the appearance of a peak at the wave number of $1404.18 \mathrm{~cm}^{-1}$. This result verifies that the modify carried out produced natural zeolites coated with iron oxide. Change in the colour of natural zeolite from grey to reddish brown was observed (Figure 2). This result indicates the presence of iron in the sample. Table 1 presents the functional groups of NZ compared to MZ. Modification of natural zeolite increase specific surface area and pore volume but decreases pore radius decreases (Table 2). This result indicates that the attached iron oxide closes the pores of natural zeolite, causing the pore radius to decrease.

Based on Figure 3 natural zeolites after being coated with iron oxide could increase microsized pores $(<20 \AA)$ and decrease meso-sized pores (20 to $500 \AA$ ). The decrease in pore radius was due to the attachment of iron oxide that increased the results of nitrate adsorption. The possible adsorption $\mathrm{NO}_{3}{ }^{-}$mechanism was con- trolled by electrostatic attraction and ionexchange as shown in Figure 4. During adsorption, the nitrate ions in salt water were replaced by the hydroxyl $\left(\mathrm{OH}^{-}\right)$ions present in MZ. The presence of positively charged $\mathrm{Fe}^{3+}$ and $\mathrm{NH}_{4}{ }^{+}$ions in in the prepared natural zeolites shows a good tendency to attract negative-

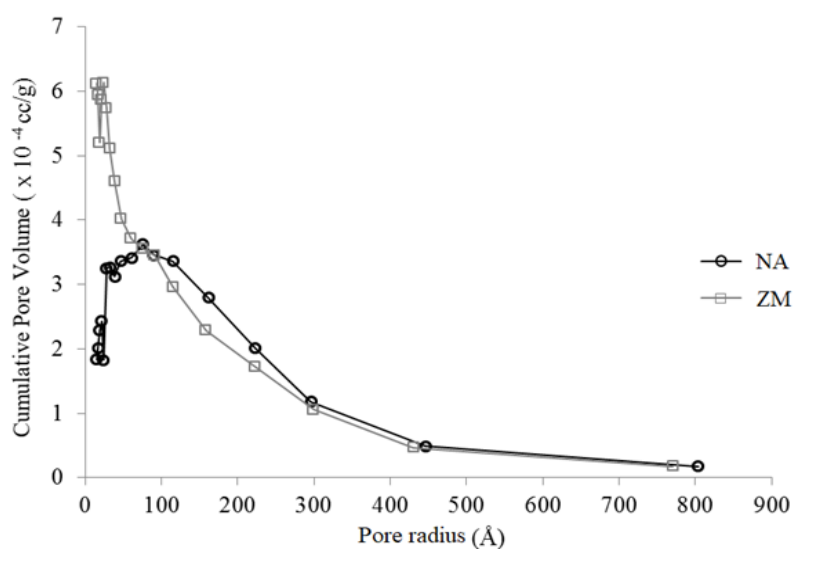

Figure 3. Distribution of adsorbent pore.

Table 1. Silica functional groups derived from the FTIR spectra recorded.

\begin{tabular}{lcc}
\hline \multirow{2}{*}{ Functional Groups } & \multicolumn{2}{c}{ Wavenumbers $\left(\mathrm{cm}^{-1}\right)$} \\
\cline { 2 - 3 } & $\mathrm{NZ}$ & $\mathrm{MZ}$ \\
\hline Stretching vibration $-\mathrm{OH}$ from $\mathrm{Si}-\mathrm{OH}$ & 3749.62 & 3749.62 \\
Bending vibration of $-\mathrm{OH}$ from water molecules & 1635.64 & 1635.64 \\
Vibration of $\mathrm{Fe}-\mathrm{O}$ & - & 1404.18 \\
Asymmetric stretching vibration of $\equiv \mathrm{Si}-\mathrm{O}$ on $\equiv \mathrm{Si}-\mathrm{O}-\mathrm{Si} \equiv$ & 1041.56 & 1041.56 \\
Symmetric stretching vibration of $=\mathrm{Si}-\mathrm{O}$ on $\equiv \mathrm{Si}-\mathrm{O}-\mathrm{Si} \equiv$ & 794.67 & 794.67 \\
Bending vibration $\mathrm{Si}-\mathrm{O}-\mathrm{Si}$ & 470.63 & 447.49 \\
\hline
\end{tabular}

Table 2. The results of the adsorbent analysis using GSA.

\begin{tabular}{lcc}
\hline Description & NA & ZM \\
\hline Specific surface area BET $\left(\mathrm{m}^{2} / \mathrm{g}\right)$ & 26.53 & 38.8 \\
Total volume pore $(\mathrm{mL} / \mathrm{g})$ & 0.1020 & 0.1052 \\
Average of pore radius $(\AA)$ & 76.89 & 54.14 \\
\hline
\end{tabular}

Table 3. List of calculated parameters of Langmuir, Freundlich, and Dubinin-Radushkevich adsorption isotherm models.

\begin{tabular}{|c|c|c|c|}
\hline Models & Equation of isotherm & Constant & $\mathrm{ZM}$ \\
\hline Langmuir & $\frac{C_{e}}{q_{e}}=-195.79 C_{e}+1216.4$ & $\mathrm{R}^{2}$ & 0.6295 \\
\hline Freundlich & $\log q_{e}=3.0286 \log C_{e}-2.8959$ & $\begin{array}{c}K_{\mathrm{F}} \\
n \\
\mathrm{R}^{2}\end{array}$ & $\begin{array}{c}5.52 \times 10^{-4} \\
0.3302 \\
0.9634\end{array}$ \\
\hline Dubinin-Radushkevich & $\ln q_{e}=-5.4153 \varepsilon^{2}-0.4013$ & $\begin{array}{c}Q_{\mathrm{D}}(\mathrm{mmol} / \mathrm{g}) \\
B_{\mathrm{D}}\left(\mathrm{mol}^{2} \cdot \mathrm{kJ}^{-2}\right) \\
E_{\mathrm{D}}\left(\mathrm{kJ}_{\mathrm{mol}}^{-1}\right) \\
\mathrm{R}^{2} \\
\end{array}$ & $\begin{array}{c}9.7 \times 10^{-2} \\
0.1616 \\
1.76 \\
0.9801 \\
\end{array}$ \\
\hline
\end{tabular}


ly charged species such as nitrate ions through electrostatic attraction.

\subsection{Adsorption Isotherm}

The equilibrium adsorption isotherms is primarily important to evaluate nitrate adsorption capacity. In order to determine the optimum isotherm model according to coefficient of determination values, Langmuir, Freundlich $\mathrm{Du}$ binin-Radushkevich models were applied to the adsorption experimental results as given in Table 3 . The Table 3 presents that the adsorption isotherms in the three systems are more likely to follow the Dubinin-Radushkevich isotherm. The value of $E$ was used to determine the type of the adsorption process. It proceeded through a cation exchange when the value obtained was between $8 \mathrm{~kJ} / \mathrm{mol}$ and $16 \mathrm{~kJ} / \mathrm{mol}$, while physisorption took place when it was less than 8 $\mathrm{kJ} / \mathrm{mol}$ [23]. The energy value found with this equation application amounted to $1.78 \mathrm{~kJ} / \mathrm{mol}$. It indicates that the bonds between the nitrate anions and MZ can be attributed to physisorption. Batch adsorption isotherms indicated that the maximum multilayer adsorption capacity of
MZ for nitrate was $9.7 \times 10^{-2} \mathrm{mmol} / \mathrm{g}$ which was higher than that of many other adsorbents reported in literature [1,9].

\subsection{Adsorption Kinetics}

The adsorption kinetics of MZ were studied using pseudo first order and pseudo second order reaction mechanisms. Based on the results shown in Table 4, the kinetic data could be best described by the pseudo second order kinetic equation. Experimental data correlate excellent to the pseudo second order reaction model with coefficient of determination value $\left(\mathrm{R}^{2}\right)$ as 0.9703 . The rate constant was $k=1.80 \times 10^{-2}$ $\mathrm{g} / \mathrm{mg}$.min. The data demonstrated the effect of nitrate concentration on the adsorption rate. Furthermore, based on the pseudo second order model, two reactions occurred; the first one was fast and reached equilibrium quickly, whereas the second one was a slow reaction that continued for an extended period. It is noted that diffusion control is the most consistent factor that is closely related to surface reactivity and porosity [26].

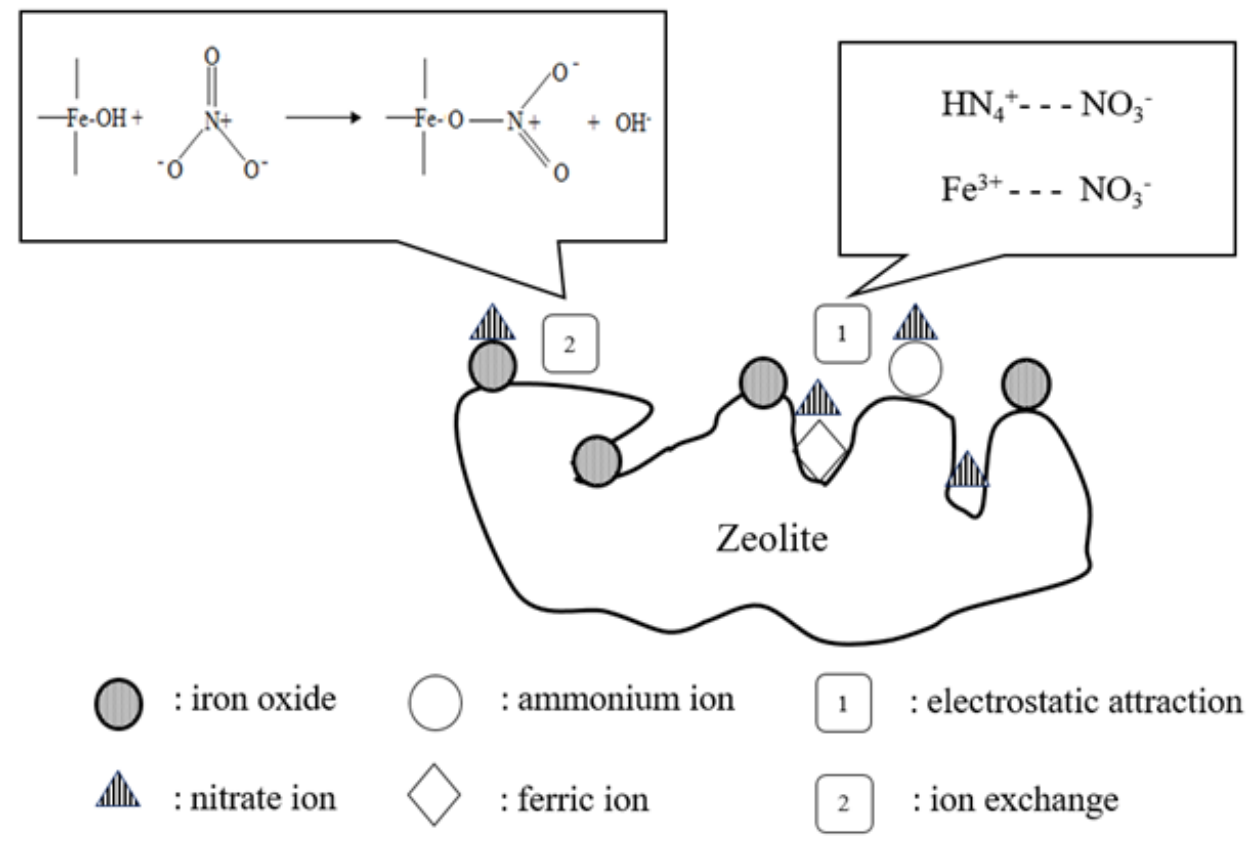

Figure 4. Proposed mechanism for the adsorption of nitrate on iron-oxide surface.

Table 4. The kinetic equation of nirate adsorption in saltwater on MZ.

\begin{tabular}{lcc}
\hline Order of reaction & Equation of reaction & $\mathrm{R}^{2}$ \\
\hline Pseudo first order & $\ln \left(q_{e}-q_{t}\right)=-0.0068 t-0.6948$ & 0.9557 \\
Pseudo second order & $\frac{t}{q_{t}}=0.7274 t+29.336$ & 0.9703 \\
\hline
\end{tabular}




\section{Conclusions}

This study investigated the adsorption characteristics of natural zeolite coated with iron oxide as a potential adsorbent for the removal of nitrate from salt water. The energy involved in the adsorption process is calculated on the Dubinin-Radushkevich model. It was found equal to $1.78 \mathrm{~kJ} / \mathrm{mole}$ verifying that physical adsorption of nitrate ions proceeds on the surface of modified zeolite. Pseudo second order model provides the best correlation of the experimental data, with rate constant of $1.80 \times 10^{-2} \mathrm{~g} / \mathrm{mg}$. min.

\section{Acknowledgments}

The authors gratefully acknowledge Chemical Analysis Study Program, Department of Chemistry, Universitas Islam Indonesia for the support to this work.

\section{References}

[1] Wu, Y., Wang, Y., Wang, J. (2016). Nitrate removal from water by new polymeric adsorbent modified with amino and quaternary ammonium groups: Batch and column adsorption study. Journal of the Taiwan Institute of Chemical Engineers, 66, 191-199. DOI: 10.1016/j.jtice.2016.06.019

[2] Yoke, L.L., Yin F.Y. (2016). Optimization of Nitrate Removal from Aqueous Solution by Amine- Functionalized MCM-41 using Response Surface Methodology. Procedia Engineering Letters, 148, 1239-1246. DOI: 10.1016/j.proeng.2016.06.485.

[3] Kim, Y.N., Kim, M.Y., Choi, M. (2016). Synergistic integration of catalysis and ionexchange for highly selective reduction of nitrate into N-2. Chemical Engineering Journal, 289, 423-432. DOI: 10.1016/j.cej.2016.01.002.

[4] Duan, S., Tong, T., Zheng, S., Zhang, X., Li, S. (2020). Achieving low-cost, highly selective nitrate removal with standard anion exchange resin by tuning recycled brine composition. Water Research, 173, 1-9. DOI: 10.1016/j.watres.2020.

[5] Richards, L.A., Vuachere, M., Andrea, I.S. (2010). Impact of $\mathrm{pH}$ on the removal of fluoride, nitrate and boron by nanofiltration/reverse osmosis. Desalination, $261, \quad 331-337 . \quad$ D O I : 10.1016/j.desal.2010.06.025.

[6] Epsztein, R., Nir, O., Lahav, O., Green, M. (2015). Selective nitrate removal from groundwater using a hybrid nanofiltrationreverse osmosis filtration scheme. Chemical Engineering Journal, 279, 1, 372-378. DOI: 10.1016/j.cej.2015.05.010.
[7] Koter, S., Chojnowska, P., Szynkiewicz, K., Koter, I. (2015). Batch electrodialysis of ammonium nitrate and sulfate solutions. Journal of Membrane Science, 496, 219-228. DOI: 10.1016/j.memsci.2015.08.064.

[8] Belkada, F.D., Kitous, O., Drouiche, N., Aoudj, S., Bouchelaghem, O., Abdi, A., Grib, H., Mameri, N. (2018). Electrodialysis for fluoride and nitrate removal from synthesized photovoltaic industry wastewater. Separation and Purification Technology, 204, 108-111. DOI: 10.1016/j.seppur.2018.04.068.

[9] Hu, R., Zheng, X., Zheng, T., Xin, J., Wang, H., Sun, Q. (2019). Effects of carbon availability in a woody carbon source on its nitrate removal behaviour in solid-phase denitrification. Journal of Environmental Management, $246, \quad 832-839 . \quad$ D O I : 10.1016/j.jenvman.2019.06.057.

[10] Wu, Z., Xu, F., Yang, C., Su, X., Guo, F., Xun, Q., Peng, G., He, Q., Chen, Y. (2019). Highly efficient nitrate removal in a heterotrophic denitrification system amended with redoxactive biochar: A molecular and electrochemical mechanism. Bioresource Technology, 275, 297-306. DOI: 10.1016/j.biortech.2018.12.058.

[11] Dewage, N.B., Liyanage, A.S., Pittman, C.U., Mohan, D., Isna, T.M. (2018). Fast nitrate and fluoride adsorption and magnetic separation from water on $\mathrm{a}-\mathrm{Fe}_{2} \mathrm{O}_{3}$ and $\mathrm{Fe}_{3} \mathrm{O}_{4}$ dispersed on Douglas fir biochar. Bioresource Technology, 263, 258-265. DOI: 10.1016/j.biortech.2018.05.001.

[12] Kuang, P., Chen, N., Feng, C., Li, M., Dong, S., Lv, L., Zhang, J., Hu, Z., Deng, Y. (2018). Construction and optimization of an iron particle-zeolite packing electrochemicaladsorption system for the simultaneous removal of nitrate and by-products. Journal of the Taiwan Institute of Chemical Engineers, 86, 101-112. DOI:10.1016/j.jtice.2018.02.023.

[13] Orimi, R.G., Mirzayi, B., Nematollahzadeh, A., Tardast, A. (2018). Competitive adsorption of nitrate in fixed-bed column packed with bio-inspired polydopamine coated zeolite. Journal of Environmental Chemical Engineering, 6, 2232-2240. DOI: 10.1016/j.jece.2018.01.049.

[14] Fan, C., Zhang, Y. (2018). Adsorption isotherms, kinetics and thermodynamics of nitrate and phosphate in binary systems on a novel adsorbent derived from corn stalks. Journal of Geochemical Exploration, 188, 95100. DOI: 10.1016/j.gexplo.2018.01.020.

[15] Maulana, I., Takahashi, F. (2018). Cyanide removal study by raw and iron-modified synthetic zeolites in batch adsorption experiments. Journal of Water Process Engineering, 22, 80-86. DOI: 10.1016/j.jwpe.2018.01.013. 
[16] Liu, T., Wang, H., Zhang, Z., Zhao, D. (2017). Application of synthetic iron-oxide coated zeolite for the pollution control of river sediments. Chemosphere, 180, 160-168. DOI: 10.1016/j.chemosphere.2017.04.023.

[17] Gan, L., Zuo, J., Xie, B., Li, P., Huang, X. (2012). Zeolite (Na) modified by nano-Fe particles adsorbing phosphate in rainwater runoff. Journal of Environmental Sciences, 24, 1929-1933. DOI: 10.1016/S10010742(11)61035-8.

[18] Shukla, E.A., Johan, E., Henmi, T., Matsue, N. (2013). Arsenate adsorption on iron modified artificial zeolite made from coal fly ash, Procedia Environmental Sciences, 17, 279284. DOI: 10.1016/j.proenv.2013.02.039.

[19] Suratno, S. (2013). Phosphate Ion Adsorption in Freshwater and Seawater Using Commercial Natural Zeolite Coated with Iron Oxide. Thesis, Department of Chemistry, Gadjah Mada University.

[20] Monteiro, M.I.C., Ferreira, F.N., Oliveira, N.M.M., Avila, A.K. (2003). Simplified version of the sodium salicylate method for analysis of nitrate in drinking waters. Analytica Chimica Acta, 477, 125-129. DOI: 10.1016/S00032670(02)01395-8.

[21] Langmuir, I. (1918). The adsorption of gases on plane surfaces of glass, mica and platinum. Journal of the American Chemical Society, 40, 1361-1403. DOI: 10.1021/ja02242a004.
[22] Freundlich, H., Heller, W. (1939).The Adsorption of cis- and trans-azobenzene. Journal of the American Chemical Society, 61, 22282230. DOI: 10.1021/ja01877a071.

[23] Itodo, A.U., Itodo, H.U., (2010), Sorption Energies Estimation Using Dubinin Radushkevich and Temkin Adsorption Isotherms, Life Science, 7, 31-39. DOI: 10.7537/marslsj070410.05.

[24] Ho, Y. S. (2004). Citation review of Lagergren kinetic rate equation on adsorption reactions, Scientometrics. 59, 171-177. DOI: 10.1023/B:SCIE.0000013305.99473.cf.

[25] Ho, Y.S., Mckay, G. (1998). Sorption of dye from aqueous solution by peat. Chemical Engineering Journal, 70, 115-124. DOI: 10.1016/S0923-0467(98)00076-1.

[26] Aman, A., Ahmed, D., Asad, N., Masih, R., Rahman, H. M. A. (2018). Rose biomass as a potential biosorbent to remove chromium, mercury and zinc from contaminated waters. International Journal of Environmental Studies, 75, 774-787. DOI: 10.1080/00207233.2018.1429130.

Selected and Revised Papers from $3^{\text {rd }}$ International Conference on Chemistry, Chemical Process and Engineering 2020 (IC3PE 2020) (https://chemistry.uii.ac.id/ic3pe/) (Universitas Islam Indonesia (UII), Labuan Bajo, Nusa Tenggara Timur, Indonesia by 30 ${ }^{\text {th }}$ September - $1^{\text {st }}$ October 2020) after Peer-reviewed by Scientific Committee of IC3PE 2020 and Peer-Reviewers of Bulletin of Chemical Reaction Engineering \& Catalysis. Editors: Is Fatimah, I. Istadi. 